\title{
Katarzyna Warmińska*
}

\author{
Uniwersytet Ekonomiczny w Krakowie
}

\section{O TOŻSAMOŚCI I POLITYCE}

\begin{abstract}
Ostatnie dekady przyniosły znaczące zmiany w sferze stosunków etnicznych w Polsce. Można było zaobserwować wzrastającą aktywność społeczności mniejszościowych, które stają się w coraz większym stopniu aktywnymi, coraz lepiej zorganizowanymi aktorami na scenie publicznej. W bardziej otwarty sposób komunikują swoje potrzeby, cele i wizje świata. Chcąc uchwycić istotę tych przemian postanowiłam zaaplikować, do ich analizy, koncepcję polityki tożsamości. Moim celem jest ukazanie swoistej „logiki” działania politycznego grup tożsamościowych, ze szczególnym uwzględnieniem jego wymiaru etnicznego z jednoczesnym wskazaniem na pożytek z zastosowania tego pojęcia do analizy zjawisk etnicznych w Polsce. Jako empiryczną egzemplifikację potraktowałam społeczność kaszubską.
\end{abstract}

Słowa kluczowe: etniczność, polityka tożsamości, Kaszubi

O uwikłaniu tożsamości w sferę polityki dużo się mówi i pisze ostatnimi czasy. Jak wskazują Avigail Eisenberg i Will Kymlicka (2011), okres minionych trzydziestu lat można nazwać erą polityki tożsamości, kiedy to wiele grup organizowało swą aktywność w sferze polityki właśnie w odniesieniu do podzielanej w ich obrębie wizji siebie jako podmiotu kolektywnego. Patrząc z dzisiejszej perspektywy, łatwo zauważyć, że nie jest to zjawisko nowe. Cofając się w czasie, można dostrzec pewne podobieństwa na przykład między współcześnie obserwowanymi procesami etnicznymi a XIX-wiecznymi zmaganiami budzicieli narodowych dążących do uzyskania uznania dla dążeń politycznych czy kulturowych (oczywiście należy pamiętać o zasadniczych różnicach płynących z odmiennego kontekstu historycznego i społecznego). Mimo to jednak trudno jest wskazać jednoznacznie ciagłość między przeszłością a teraźniejszością, gdyż ta druga, ze względu na jej podstawowe parametry (globalizacja, homogenizacja, heterogenizacja, mobilność, cyfryzacja itp.) nie tylko akceleruje wcześniejsze zjawiska, ale nadaje im inny, swoisty kształt. Jak piszą wspomniani badacze, nie tylko wiele nowych podmiotów wyłania się na arenie społecznych relacji, ale też długotrwałe grupy tożsamościowe repolityzują się (po czasach względnego spokoju) i dążą do przeformułowania warunków uczestnictwa w społeczeństwie.

* Adres do korespondencji: Katarzyna Warmińska, Katedra Socjologii, Wydział Ekonomii i Stosunków Międzynarodowych, Uniwersytet Ekonomiczny w Krakowie, ul. Rakowicka 27, 31-510 Kraków, e-mail: kwarminska@o2.pl 
Można powiedzieć, że polityka tożsamościowa staje się elementem życia społecznego w wielu miejscach; ma różne podstawy, przebieg i skutki, ale jest zjawiskiem na tyle specyficznym, że pozwala się opisać w uporządkowany sposób. Należy jednak zwrócić uwagę na to, że wśród badaczy tego fenomenu można wskazać zarówno takich, którzy skupiają się na opisie i analizie zjawiska w poszczególnych jego przejawach, jak i takich, którzy przyjmują stanowisko krytyczne wobec polityki tożsamości jako takiej, takich, którzy w sposób krytyczny piszą o jej janusowym obliczu, a także takich, którzy skupiają się na jej etycznym wymiarze i wartościują ją pozytywnie.

Moim celem będzie ukazanie swoistej „logiki” działania politycznego grup tożsamościowych, ze szczególnym uwzględnieniem jego etnicznego wymiaru z jednoczesnym wskazaniem na pożytek z zastosowania tego pojęcia do analizy zjawisk etnicznych w Polsce.

Do czego więc analizowana tu koncepcja polityki tożsamości się odnosi?

W aspekcie opisowym należy zwracać uwagę na powiązania między życiem politycznym a tożsamością i tym samym rozważać pewien rodzaj aktywności aktorów społecznych w obszarze usytuowanym na przecięciu tych dwóch osi, wskazując na formy przejawiania się takich działań oraz na szersze historyczne czy społeczne ich przyczyny, konteksty. W praktyce społecznej można obserwować różne grupy tożsamościowe zmobilizowane politycznie na bazie tubylczości, płci, rasy, języka, etniczności czy religii.

Najogólniej rzecz biorąc, ta sfera społecznej działalności powiązana jest z kwestią dążenia do uzyskania społecznego uznania dla danych identyfikacyjnych wyborów, a jest polityczna, gdyż uwikłana jest w sieć interesów, potrzeb oraz relacji władzy. Pojęcie to jest używane przede wszystkim na określenie działalności grup społecznych doświadczających marginalizacji i nierównego traktowania.

W centrum zainteresowania znajdują się takie szersze problemy jak miejsce tożsamości w obrębie polityki i kultury, nowe formy integracji społecznej, relacje między strukturą a działaniem podmiotowym, aktywizm kulturowy, zagadnienia związane z opresją i panowaniem (Gupta 2007). Zwraca się więc uwagę na takie poczynania jak artykulacja czy afirmacja danych wizji świata w odniesieniu do kontekstu identyfikacyjnego. Wizje te stają się podłożem walki politycznej, której celem jest mobilizowanie tych wizji na arenie życia społecznego jako elementu walki politycznej, u podłoża której leży ustanowienie nowych form podmiotowości będących w opozycji do różnych reżimów władzy. Tożsamość staje się rodzajem praktyki.

W ten sposób wymiar polityczny i identyfikacyjny splatają się i mamy do czynienia w pewnym sensie z naturalną produkcją kategorii politycznych, które oparte są na atrybutach zaangażowanych podmiotów; pozwalają wspólnotom rościć sobie prawa do równego traktowania, swobody działania czy udziału w demokratycznym rządzeniu. Ważny jest zarówno aspekt samouznania i bycia uznanym przez innych, a jego poszukiwanie jest dążeniem do objęcia władzy nad samoopisem, ale także jest odmową brania za własne tych tożsamości, które inni życzą sobie w drugich rozpoznawać.

Wizja tożsamości, która leży u podstawy tego działania, zakłada istnienie jasnej zasady desygnacji pewnych grup, których tożsamość jest względnie stała i określona. Dotyczy to zarówno samych zainteresowanych, jak i ich szeroko rozumianego otoczenia społecznego czy też społecznego dyskursu (w wymiarze zinstytucjonalizowanym i publicznym; na poziomie mikro, median, makro czy globalnym). 
Nie ma tu dużej tolerancji płynności czy niepewności układów identyfikacyjnych. Co więcej, polityka tożsamości opiera się na totalizacji tożsamości i wysoce scentralizowanych wizjach podmiotowości, indywidualnych i kolektywnych. W centrum lokuje się nie tyle tożsamość rozumiana jako zjawisko kontekstowe czy sytuacyjne, negocjowane vis a vis innych $\mathrm{w}$ interakcjach społecznych, gdzie kluczem do rozumienia roli identyfikacji w działaniach społecznych jest refleksyjność, wybór czy płynność oraz w pewnym stopniu strukturalne położenie aktora.

Polityka tożsamości odnosi się wyraźnie do specyficznie ujmowanego obszaru tożsamościowego. Stąd charakterystyczna dla tego zjawiska społecznego presja na jednakowość, skłonność do esencjalizacji, która powoduje, iż formułowane dążenia zdają się formułowane przez kategorię ludzi, którzy rzekomo podzielają daną tożsamość. Skutkuje to, zdaniem Craiga Calhouna, wyabstrahowaniem tożsamości z logiki codziennych kontaktów, podczas których jest ona negocjowana, na rzecz twardego jej rozumienia, gdzie złożona i wieloraka jej istota zostaje sprowadzona do oderwanej od społecznego konkretu zamkniętej kategorialnej jej wersji. Zakłada się jednocześnie, iż dany kategorialny opis dominuje nad innymi aspektami. Zjawisko to wyrażające dążenie do wzmocnienia rangi takich kategorialnych tożsamości na poziomie grupowym nazywa autor wewnątrzgrupowym esencjalizmem związanym z portretowaniem tożsamości jako pojedynczych, ustanowionych, niezmiennych, często w sposób wyostrzony zestawianych z dominującymi kategoryzacjami tożsamości. Każda tożsamość kolektywna narażona jest zarówno na wewnętrzny podział, jak i dążenia do jego likwidacji przez włączenie odmienności w obręb większej kategorii, którą jest podstawowa, główna tożsamość (Calhoun 1994: 22-24).

Podmiot poddany jest zarówno logice pola politycznego, jak i naciskowi ze strony danej definicji „my”, w której powinien odnajdywać odpowiedź na pytanie, kim jest i do czego dąży.

Socjologowie krytyczni, zwłaszcza piszący z pozycji konstruktywistycznych, zwracają szczególną uwagę na wspomniany wyżej proces esencjalizacji czy totalizacji tożsamości, który jest elementem politycznej gry tożsamościowej, a może nawet i elementem ją konstytuującym. Za Sumanem Guptą można powiedzieć, iż esencjalistyczny argument pojawia się gdy , ,... [ mamy do czynienia z niezbywalnymi i esencjalnymi różnicami między różnymi kolektywami wyznaczanymi na bazie tożsamości, zwłaszcza gdy są one definiowane względem siebie wzajemnie" (Gupta 2007: 23).

Esencjalizacja tożsamości w przypadku polityki tożsamości przybiera dwa oblicza. Po pierwsze, prowadzi do budowania charakterystyki podmiotu wokół jednej naczelnej osi, co powoduje narzucenie pewnej dyscypliny opisu czy samoopisu, zastępując, zdaniem krytyków, tyranię jednego opresyjnego opisu preferowanego przez grupę dominującą przez tyranię innego. W konsekwencji postulaty działania tworzone są w imieniu narzuconej pojedynczej cechy definiującej jednostkę. Po drugie, owe generalizacje czynione na temat podmiotu zbiorowego przestają mieć tylko funkcję opisującą, a nabierają mocy dyscyplinującej członków grupy, którym narzucona zostaje dana forma deskrypcji i którą powinni podzielać. Mamy więc do czynienia z dwiema praktykami dyscyplinującym: tą realizowaną przez grupę dominująca, która narzuca pewną wizję owych zmarginalizowanych podmiotów, oraz drugą, wewnątrzgrupową. 
Do głosów krytycznych dołączają się także poststrukturaliści, którzy, zdaniem Cressidy Heyes, przede wszystkim zwracają uwagę na błędny, ich zdaniem, obraz podmiotu w polityce tożsamości jako posiadającego metafizyczną substancję, esencjalne atrybuty, które definiują tożsamość. W zamian proponują alternatywą wizję tożsamości jako produktu dyskursu, czegoś, co jest potencjalne, a zarazem uwikłane w splot możliwości i ograniczeń. Podstawowym zagrożeniem jest więc to, że na mocy tej praktyki jednostce czy grupie narzucone zostaje jako autentyczne to (tożsamość), co w gruncie rzeczy jest pochodną różnicy wobec Innego (Heyes 2002).

Oprócz zarzutów skupiających się na problematyce esencjalizacji tożsamości (formułowanych z różnych punktów widzenia) do argumentów przeciw dorzuca się też te odwołujące się do faktycznych skutków działań pod hasłem dążeń do uzyskania uznania formułowanych przez grupy tożsamościowe (często pojawiają się odwołania do krwawej logiki identyfikacyjnej stosowanej podczas wojny w byłej Jugosławii). Także i z tych powodów, zdaniem Jamesa Clifforda, polityka tożsamości nie ma dobrej prasy. Jest atakowana przez tych, którzy piszą o jej negatywnym wpływie na narodowe tradycje czy też na konsensualnie rozumianą sferę obywatelską. Dalej podkreśla się jej burzącą moc w kontekście wysiłków skierowanych na kumulatywnie rozumiany społeczny opór (stanowiska lewicowe) oraz skłonność ku esencjalizacji tożsamości (Clifford 2000: 94).

Można wskazać na te stanowiska, zwłaszcza filozoficzne, wedle których opisywane zjawisko nabiera bardziej pozytywnej konotacji, zwłaszcza jeśli usytuuje się je w kontekście dyskursu etycznego. Jak piszą Avigail Eisenberg i Will Kymlicka, myśliciele polityczni, którzy przyjmują stanowisko normatywne, roszczenia tożsamościowe umieszczają w odniesieniu do wartości takich, jak sprawiedliwość, wolność, prawa człowieka czy prawa obywatelskie w społeczeństwie demokratycznym. Stąd też działania w sferze polityki tożsamości traktują jako wyraz dążeń emancypacyjnych podmiotu kolektywnego czy indywidualnego, realizację pragnień uzyskania uznania i prawa do samostanowienia (Eisenberg i Kymlicka 2011).

Jak wspominałam wcześniej, część badaczy problematyki polityki tożsamości mówi o jej janusowym obliczu. Z jednej strony mamy refleksję nad jej negatywnymi społecznymi skutkami (np. wojny w imię tożsamości), wskazującą na manipulację delikatną naturą ludzkiej tożsamości, socjotechniki stosowane przez liderów czy władzę hegemoniczną. Z drugiej zaś można uznać ją za kolektywne samopotwierdzenie oraz wyraz szlachetnych aspiracji wspólnot. James Clifford zwraca uwagę, powołując się na Stuarta Halla, że rysem charakterystycznym współczesnych społeczeństw, zwłaszcza tych liberalno-demokratycznych, jest kolektywne sprawstwo wyrażające się w zwiększającej się roli kulturowych, etnicznych czy rasowych identyfikacji w sferze polityki. Ludzie stają się aktywnymi aktorami i obejmują te pozycje, które można określić jako tożsamościowe. Czynią tak, gdyż potrzebują dla siebie miejsca w zatłoczonym świecie. W otoczeniu stabilnym, w społeczeństwie obywatelskim efektywne grupowe działanie zmierzające do samopotwierdzenia obejmuje przedsięwzięcia, które mają na celu skupianie się czy docieranie w obrębie danej grupy tożsamościowej, czyli łączenie, przy jednoczesnym oddzielaniu się, wyodrębnianiu się w społecznym świecie (Clifford 2000: 96-97).

Procesy, na mocy których dochodzi do owego fussion / fission obejmują zarówno konflikt, jak też koalicję, negocjacje i wojny. Stąd nie można jednoznacznie ocenić tego procesu. Jak 
konstatuje James Clifford, efektywna demokratyczna mobilizacja zaczyna się tam, gdzie są ludzie, którzy wespół używają kulturowego dyskursu, który to sytuuje grupy w świecie, daje korzenie, tradycje, odrębne społeczne habitusy i ciała (Clifford 2000: 97).

Są jednak i tacy, którzy widzą w tych działaniach zagrożenie dla demokratycznie zorganizowanej wspólnoty obywateli, wskazując, że rozbijają one społeczny konsensus oparty na rozumie i kompromisie, zwłaszcza że mobilizacja w imię tożsamości podkreśla odmienności, a zasoby (identyfikacja), które są przedmiotem działania, są „nienegocjowalne” racjonalnie.

Wspomniane wyżej kwestie skłaniają też do rozważania sposobu rozumienia istoty polityki czy polityczności, w kontekście których ujmujemy opisane wyżej procesy tożsamościowe. Można, moim zdaniem, wpisać je w obszar wyznaczony przez dwa bieguny. Pierwszy oznaczałby przyjęcie założenia, iż polityka/polityczność to przestrzeń wolności i deliberacji, drugi natomiast zakładałby, że ich istotą jest przestrzeń konfliktu i antagonizmu. Stąd dzialanie polityczne (politics of identity) można rozumieć różnorako, począwszy od przyjęcia założenia, iż mamy do czynienia z podmiotami uwikłanymi w nierozwiązywalny w systemie demokratycznym układ sprzeczności (np. agonistyczna koncepcja polityki w ujęciu Chantal Mouffe), skończywszy na konsensualnym jej ujęciu jako wspólnego dążenia do uzyskania zgody w sprawach publicznych (np. koncepcja Jürgena Habermasa, Hannah Arendt). Wtedy, w zależności od przyjętej perspektywy, analizuje się przyczyny, przebieg czy skutki politycznej mobilizacji grup tożsamościowych.

Tożsamość staje się upolityczniona nie tylko, gdy walka toczy się o symboliczne uznanie i legitymizację dla etnicznych, religijnych czy płciowych tożsamości, tradycyjnie uznawanych za gorsze w stosunku do tych dominujących. Dotyczy też redystrybucji zasobów. Za tymi działaniami kryje się bowiem przekonanie, iż tożsamości dopóty są zagrożone, dopóki nie uzyskają politycznego wsparcia (Miller 2000: 66).

Podsumowując, można powiedzieć, iż w zależności od przyjętego stanowiska polityka tożsamości ma zarówno wymiar egzystencjalny, normatywny, emancypacyjny, jak i strategiczny; oddaje istotę ludzkiej tożsamość lub prowadzi do jej zniekształcenia czy zanegowania; traktowana jest jako działanie uprawomocnione, ale też niebezpieczne; wyraźnie pozytywne lub negatywne.

Jak wspominałam na początku artykułu, tym, co mnie szczególnie interesuje, jest polityka tożsamości w kontekście etnicznym. Nie chcąc się lokować na pozycji krytycznej, a zarazem pamiętając o janusowym obliczu zjawiska, o którym to zaledwie wspomniałam, chciałabym zwrócić uwagę na specyfikę spolitycyzowanych zjawisk identyfikacyjnych występujących w tym kontekście.

Chcąc odnieść koncept polityki tożsamości do sfery stosunków etnicznych, można za Thomasem H. Eriksenem wskazać, iż ma ona przede wszystkim charakter glokalny, osadzona jest na danym terytorium, w historii, odnosi się do konkretnej grupy, choć musi, jak wszystko, co ma ów lokalny charakter w dobie globalizacji, odnosić się do szerokiego dyskursu kultury i praw. Kryje się za nią chęć przywołania tradycji, sentyment etniczny, religijny czy kulturowy, który jeśli uznany zostanie za znajdujący się w stanie oblężenia, uruchamia szereg działań. Można, zdaniem przywołanego autora, spotkać wiele odmian polityki tożsamości, począwszy od narodowych ruchów separatystycznych, przez działania represjonowanych mniejszości żądających równych praw, na aktywności ze strony większości chroniącej swe 
zasoby narodowe przed mniejszościami skończywszy; ma ona wymiar religijny, etniczny, regionalny (Eriksen 2009: 2013).

Kluczowe, moim zdaniem, punkty, które trzeba brać pod uwagę, analizując omawianą tu politykę tożsamości w sferze etnicznej, to:

- usytuowanie i uznanie tożsamości w aspekcie indywidualnym, ale przede wszystkim kolektywnym, jako głównej siły sprawczej w relacjach społecznych oraz jako zasobu będącego $\mathrm{w}$ posiadaniu podmiotów;

- zdefiniowanie tożsamości jako zagrożonej, nieuprzywilejowanej w relacjach etnicznych, co pociaga dążenie do jej ochrony lub dążenie do poprawy jej położenia;

- istnienie nierównego rozdziału zasobów zarówno symbolicznych, jak i materialnych w polu etnicznym (odwołując się to koncepcji Pierre'a Bourdieu), rozumianego tu jako zjawisko o charakterze glokalnym;

- mobilizacja zasobów tożsamościowych polegająca na podejmowaniu zabiegów mających na celu stworzenie czy zdefiniowanie podmiotu kolektywnego jako składającego się z ludzi tego samego rodzaju, co prowadzi do zacierania różnic wewnętrznych i dominacji idei podobieństwa;

- proces domykania złożonych tożsamości, która w konsekwencji pozwala mówić w obrębie dyskursu etnicznego z pozycji podmiotu o danych, dookreślonych właściwościach;

- aktywność polityczna (politics) w jej różnych przejawach, prowadzona w imię danej wizji charakterystyk podmiotu kolektywnego, a przede wszystkim dążenie do uzyskania uznania dla jego sprawstwa w sferze politycznej.

Na końcu należy podkreślić, że uprawianie polityki tożsamości jest możliwe, jeśli w polu politycznym i etnicznym funkcjonują pozycje ustanawiające podmioty kolektywne desygnowane, opierające się na kategoriach tożsamości.

Stąd badacze zwracają uwagę, że dopiero w obrębie porządku demokratycznego etniczność staje się istotnym pojęciem w sferze polityki czy prawa, co zgodne jest z oficjalnym dyskursem, na mocy którego przykładowo ustanawia się ramy dla ochrony mniejszości czy indywidualnej tożsamości kulturowej. System ów to swoista nadbudowa nad społecznymi stosunkami, której istotnym komponentem są większości i mniejszości, centra i peryferie, tożsamość. Jednak aby mógł on trwać, potrzebna jest nieustająca jego racjonalizacja i uzasadnianie, które bierze za główne kryterium swoiste dla liberalnego porządku zobowiązanie i dobre intencje wobec mniejszości, ale też większości (Gupta 2007: 65-66; Eriksen 2013).

Pojęcia używane w polityce tożsamości na oznaczenie relacji między pozycjami, przykładowo koalicja, pluralizm, różnica, mają prawie mistyczne znaczenie (Gupta 2007).

Należy też zaznaczyć, że dyskurs ten ma charakter hegemoniczny i zakłada, iż każdy jest etnicznie ulokowany na pozycji większościowej/centralnej lub mniejszościowej/peryferyjnej, a różnica dotyczy zakresu, w jakim podmioty akceptują ów porządek, a tym samym zasady polityki tożsamości, a w jakim go kontestują. Stąd też o polityce tożsamości w Polsce można mówić od przełomu politycznego w 1989 roku.

Jak zauważa E.T. Eriksen, logika klasyfikacji funkcjonująca w państwie liberalnym raczej zachęca graczy tożsamościowych do tworzenia pozornie stabilnych i urzeczowionych wspólnot 
etnicznych. Za Gerdem Baumanem pisze, że w tym obszarze mamy do czynienia z dialogiem między, z jednej strony, konceptualizacją kultury, wspólnoty i etniczności, z drugiej zaś konceptualizacją podmiotów etnograficznych. Co ważne, G. Bauman wskazuje na istnienie dwóch typów dyskursów dotyczących etniczności. Pierwszy nazywa dyskursem dominującym, zwykle odtwarzanym w sektorze publicznym oraz w mediach, gdzie kultura, wspólnota i grupa etniczna stapiają się w jedno, ,[...] jedna wspólnota etniczna stanowi wspólnotę dzielącą tę samą kulturę" (Eriksen 2013: 224). Drugi określany jako dyskurs demotyczny, codzienny, bardziej elastycznie traktuje tożsamość, jako sytuacyjną i wielopłaszczyznową. Zwraca też uwagę, że dyskurs dominujący ma charakter hegemoniczny, ludzie muszą w nim mówić, tłumaczyć i formułować swe żądania (Eriksen 2013).

W odniesieniu do omówionych wyżej zjawisk można pokazać swoistą logikę działania w obszarze polityki tożsamości i sprowadzić ją do czterech powiązanych ze sobą zasadniczych elementów.

Najogólniej rzecz ujmując, ci, którzy politykę tożsamościową uprawiają zwykle w mniej lub bardziej uporządkowany i świadomy sposób, chcą znaleźć odpowiedź na następujące pytania: Kim jesteśmy? Jakie jest nasze położenie i dlaczego? Do czego dążymy? Jakie są nasze cele? Co robimy?

Dlatego po pierwsze muszą ustanowić podmiot kolektywny; po drugie, ulokować go na politycznej pozycji, czyli zdefiniować jego położenie w relacjach społecznych jako zmarginalizowanego czy nieuprzywilejowanego oraz wskazać najważniejszych partnerów w ich obrębie; po trzecie, sformułować postulaty czy zadania mające na celu przeformułowanie czy zmianę tego położenia na takie, które odpowiadałoby istniejącemu „my”; po czwarte, podjąć aktywności w sferze symbolicznej lub materialnej, mające owe zadania ukonkretnić.

W tekście tym skupię swoją uwagą na pierwszym aspekcie, tu określonym jako ustanowienie podmiotu kolektywnego. Jest to kluczowy moment, gdyż podmiot może wejść do gry politycznej dopiero wtedy, gdy ucieleśni się w postaci esencjalnie istniejącej wspólnoty. Jak pisał Suman Gupta, ,pozycje są obejmowane w odniesieniu do, dla i w imieniu specyficznych, opartych na tożsamości grup" (Gupta 2007: 5). Stąd polityczna aktywność w sferze tożsamościowej wymaga przede wszystkim określenia podmiotu zbiorowego, w imię którego się „,mówi”, który działa, jest zmarginalizowany, a którego interes czy istnienie są zagrożone ze względu na nierówne położenie w relacjach społecznych.

Dopiero bowiem ta wspólnota, która identyfikuje się lub jest identyfikowana w odniesieniu do podzielanej tożsamości kolektywnej, może autorytatywnie i z dużą dozą autentyczności przyjąć polityczną pozycję odpowiednią dla siebie.

Polityka tożsamości ogranicza się więc do grup, które mogą ucieleśnić te pozycje. Tym samym oznaczniki, za pomocą których określana jest tożsamość indywidualna, podporządkowane zostają oznacznikom kolektywnym na mocy procesu selekcji markerów identyfikacyjnych, a jednostka zostaje zredukowana do jednego wymiaru. Do celów politycznych dany samoopis staje się wspólnym denominatorem członków społeczności, którzy zdają się podzielać doświadczenia, aspiracje i w konsekwencji pewien rodzaj lojalności (Gupta 2007: 6). Pojawia się więc „my”, przybierające postać zesencjalizowanej wspólnoty. Esencjalizacja tożsamości jest w tym kontekście najistotniejszym zabiegiem i punktem wyjścia w sferze polityki identyfikacyjnej. 
Utrzymanie przekonania o materialności tożsamości opiera się na retorycznych zabiegach, które zawierają żargon autentyczności, dzięki czemu zmarginalizowani mogą być takimi, jakimi są.

Jak pokazała praktyka życia społecznego w ostatnich dwóch dekadach w Polsce, pojęcie „tożsamość” stopniowo stawało się istotnym elementem dyskursu politycznego, jest często przywoływane w różnych kontekstach: narodowym, europejskim, genderowym czy mniejszościowym.

Ostatnie dwudziestolecie to czas obfitujący w wiele interesujących dla badacza problematyki etnicznej w Polsce zjawisk. Patrząc szerzej, można powiedzieć, że pierwsze lata po zmianie systemowej kazały brać pod uwage dwie tendencje obserwowane w wielu krajach Europy Środkowo-Wschodniej. Pierwsza to żądania emancypacyjne dominujących grup kulturowych, których prawa polityczne i kulturowe były w okresie powojennym ograniczane. Druga zaś to działania na rzecz praw mniejszości kulturowych, których potrzeby i dążenia uznano za uprawnione w tworzących się społeczeństwach obywatelskich (Mucha 2008). Co więcej, w kraju takim jak Polska, gdzie po okresie ideologicznego komunizmu nastapiło przekierowanie dyskursu etnicznego w stronę modelu liberalnego, pojawiły się zmiany w polu stosunków etnicznych. Nie tylko grupa dominująca negocjuje własne rozumienie ,polskości”, czynią to też mniejszości narodowe i etniczne usiłujące odnaleźć swe miejsce, wspólnotę tożsamości - etnos - w nowo ustanowionym porządku ideologicznym, prawnym i instytucjonalnym.

Kiedy na początku pierwszej dekady XXI wieku Ewa Nowicka rozważała przemiany polskiej etniczności, wskazywała wtedy na pojawienie się nowych wymiarów tego zjawiska, a mianowicie postępującą instrumentalizację i instytucjonalizację i politycyzację, na zmianę więzi etnicznej z nawykowej na ideologiczną. Kazało to patrzeć na etniczność nie tylko jako ekspresję budzących się ponownie w okresie po 1989 roku etnosów, uwolnionych spod restrykcyjnej polityki państwa, ale też jako aktywność o bardziej zorganizowanym kształcie (Nowicka 2004: 11-12).

Można postawić pytanie, czy po dziesięciu latach coś się zmieniło, a jeśli tak, to czy nie byłoby użyteczne zastosowanie omawianej tu koncepcji polityki tożsamości do analizy etniczności grup mniejszościowych w ostatnim czasie.

Jeśli przyjąć, moim zdaniem umiarkowane, stanowisko Johna L. Comaroffa i Jean Comaroff (2011: 59), zgodnie z którym etniczność może być ujmowana jako tożsamość kulturowa i jako tożsamość polityczna, gdzie to rozróżnienie każe nam widzieć jej związki z polityką jako słabe lub silne, to procesy zaznaczone przez E. Nowicką niewątpliwie nabierają bardziej wyraźnego kształtu. Mam tu na myśli postępującą politycyzację aktywności podmiotów etnicznych. Jest ona wyrazem wspomnianych wyżej zmian społeczno-politycznych, które doprowadziły do upodmiotowienia mniejszości i dookreślenia porządku prawnego w obrębie stosunków etnicznych (np. ustawa z 2005 roku). Stały się one jednostkami prawnymi (legal entity). Można też wskazać inne czynniki powiązane ze wspomnianym powyżej kontekstem makrospołecznym, ale też z pewnym, docierającym także do kraju, rodzajem dyskursu etnicznego nawiązującym do idei wielokulturowości, poszanowania i dowartościowywania różnicy kulturowej (znajduje on zresztą przełożenie na sferę prawną). Niewątpliwie wzrasta, typowy dla społeczeństw nowoczesnych, poziom refleksyjności kulturowej, poczucia upodmiotowienia, na mocy którego zainteresowani definiują swą odrębność, wyjątkowość. 
Jej skutkiem jest postawa dbałości o zasoby wspólnotowe, rozwijające się upodmiotowienie. Co więcej, zmienił się kształt pola etnicznego w porównaniu z okresem do 1989 roku. Mniejszości uczestniczą w nim z własnej woli bądź są interpelowane w kontekście większej liczby relacji, których platformą jest etniczność. Nie jest to jedynie kontekst codziennych interakcji, ale też ten zinstytucjonalizowany (większość z nich działa z pozycji podmiotów sformalizowanych np. ustawowo). Więc można mówić o wielorakiej ekspresji tożsamości, tej powierzchownej, wystandaryzowanej, ale też spontanicznej, zindywidualizowanej, twórczej. W tym sensie wyłania się zarówno instrumentalny, jak i egzystencjalny wymiar etniczności, będący wyrazem wspomnianej dbałości o własne tradycje, ale też stanowiący reakcję na poczucie zagrożenia cennych zasobów.

W mojej opinii rozpatrywana tu koncepcja polityki tożsamości jest użytecznym narzędziem analizy części zjawisk etnicznych, które możemy obserwować w ostatnich latach na polskim podwórku. W przypadku niektórych mniejszości kulturowych wyraźnie widać przejście na arenie stosunków etnicznych na pozycje polityczne definiowane odniesieniu do kolektywnych właściwości. Jednym słowem esencja staje się agencją, parafrazując słowa Johna L. Comaroffa i Jean Comaroff (2011).

Spektakularnym przykładem tego zjawiska jest chociażby to, co możemy obecnie obserwować w kontekście społeczności śląskiej czy po części kaszubskiej, łemkowskiej.

Jako ilustrację omawianych tu kwestii potraktuję przykład Kaszubów, chcąc pokazać rozterki, przed którymi stoją ci z nich, którzy zaangażowani są w grę polityczną. Nie będzie to pogłębiona analiza, lecz jedynie przybliżenie problematyki ${ }^{1}$.

Przede wszystkim w obrębie tej społeczności od co najmniej dwóch dekad toczy się kluczowa dla jej pozycji w relacjach etnicznych debata dotycząca tego, kim są Kaszubi. Odpowiedź na to pytanie ma zasadnicze znaczenie, bowiem w zależności od tego, jak się grupa dookreśli, tak też zdefiniuje swe położenie, co wpłynie na pozostałe elementy działania politycznego. Inaczej sytuuje grupę w polu etnicznym i politycznym dookreślenie jej jako grupy etnicznej, mniejszości etnicznej, społeczności posługującej się językiem regionalnym, narodu kulturowego, a te wszystkie wizje komunikowane są przez różne grupy w obrębie tej wspólnoty.

Dane ucieleśnienie pozycji w relacjach etnicznych pociąga za sobą nie tylko odmienny rodzaj i zakres argumentów w dyskursie etnicznym dotyczących uprawnień, inaczej także dookreślony zostanie charakter czy kontekst marginalizacji, inaczej sformułowane zostaną działania i cele.

I tak, jeśli Kaszubi są odrębnym narodem, jak twierdzą działacze Kaszebskiej Jednoty, a siłą napędową dla polityki tożsamości jest poczucie marginalizacji czy dyskryminacji doznawane przez grupę, to podstawowym punktem odniesienia stają się inne narody - polski czy niemiecki, które określane są jako główni antagoniści i sprawcy marginalizacji.

W przypadku zaś gdy Kaszubi określają się jako grupa, której cechą charakterystyczną jest podzielanie podwójnej tożsamości kaszubsko-polskiej² (takie stanowisko popiera Zrzeszenie

\footnotetext{
Więcej na ten temat: Warmińska 2008, 2013.

Mówią o tym wyniki badań socjologicznych nad kaszubską tożsamością prowadzone od końca lat osiemdziesiątych przez różnych badaczy; patrz na przykład: Synak 2008, Mazurek 2010.
} 
Kaszubsko-Pomorskie), antagonistą może być państwo polskie czy niemieckie, a nie polski etnos, do którego przynależność deklarują.

I tu należy wspomnieć o kolejnych aspektach związanych z dookreślaniem tożsamości i z jej esencjalizacją, a mianowicie występowaniem w grupach konkurencyjnych wizji układów tożsamościowych, co prowadzi do rywalizacji pomiędzy poszczególnymi frakcjami o dusze współziomków.

Inną ważną kwestią jest uwzględnienie takiego parametru, jakim jest zakres swobody wyboru pozycji politycznej, w odniesieniu do której dana grupa się ucieleśnia. W konkretnych przykładach empirycznych odnajdujemy różnorakie sytuacje, mamy bowiem do czynienia z zaistniałymi i utrwalonymi parametrami dyskursu etnicznego. Stąd ważny jest wspominany przez T.H. Eriksena glokalny charakter polityki tożsamości. On decyduje o tym, jak na poziomie empirycznym dany dyskurs się toczy. I tak Ustawa z dnia 6 stycznia $2005 \mathrm{r}$. o mniejszościach narodowych i etnicznych i o języku regionalnym domknęła zasady i logikę ucieleśnienia $\mathrm{w}$ aspekcie formalnym, lokując uwzględnione przez nią grupy na trzech pozycjach: mniejszości narodowej, etnicznej i grupy posługującej się językiem regionalnym. W ten sposób nie tylko powołano do życia czternaście legal entities, ale też dookreślono ich etniczną charakterystykę.

Dany porządek instytucjonalny ma swoją historię, punkty kluczowe (jak na przykład owa ustawa), stąd jego zrozumienie wymaga także wzięcia pod uwagę tego parametru. W konsekwencji, jeśli obserwujemy stopniową habitualizację i instytucjonalizację logiki ucieleśnienia $\mathrm{w}$ odniesieniu do tożsamości opartych na politycznych pozycjach, a także działania mające na celu jej podtrzymywanie, powinniśmy poczynić refleksję nie tylko nad tym, kogo ona dotyczy, lecz na jakiej podstawie integracja, wiedza i rozumienie oraz emocjonalne zaangażowanie stają się elementem gry. Dopiero w tym kontekście można, po części rozumieć działania Kaszebskiej Jednoty, która chce przyznania Kaszubom statusu mniejszości etnicznej w zamian za obecny, na mocy którego zajmują pozycję grupy posługującej się językiem regionalnym. Co ciekawe, jednocześnie deklaracje tożsamościowe głoszone przez osoby zrzeszone w tej etnicznej organizacji mają charakter narodowy - kaszubski. W mojej opinii ujawnia się tu złożona logika upolitycznionego porządku tożsamościowego. $\mathrm{Z}$ jednej strony niezorientowany obserwator sceny etnicznej w Polsce mógłby się zdziwić, słysząc deklarację: jesteśmy narodem, chcemy być uznaną mniejszością etniczną. Z drugiej zaś, znając opisane w tym tekście determinanty czy przejawy polityki tożsamości, polski kontekst, oczywiście też dynamikę kaszubskiego wewnątrzgrupowego dyskursu, można skonstatować, że ta sprzeczność jedynie ukazuje dylematy, przed którymi stoją podmioty etniczne działające z wyboru, obowiązku lub przymusu w obszarze wyznaczonym przez politykę i tożsamość.

Na zakończenie można powiedzieć za Michaelem Billigiem, iż polityka tożsamości jest filozofią pierwszej osoby liczby mnogiej, która daje asumpt do tworzenia nowych, obok już istniejących, wizji charakterystyk grup etnokulturowych (Billig 2008: 290). Napędzana przez poczucie marginalizacji czy nierównego traktowania, którego doświadczają podmioty zbiorowe, prowadzi do budowania, ale też negocjowania z innymi (współziomkami, grupa dominująca) danego samoopisu. Jest, parafrazując słowa Johna i Jean Comaroffów, swoistą IDeologia. 


\section{BIBLIOGRAFIA}

Billig, Michael. 2008. Banalny nacjonalizm, Kraków: Znak.

Calhoun, Craig. 1994. Social Theory and the Politics of Identity, w: Craig Calhoun (red.), Social Theory and the Politics of Identity, Oxford: Blackwell, s. 9-36.

Clifford, James. 2000. Taking Identity Politics Seriously: the Contradictory, Stony Ground..., w: Paul Gilroy, Lawrence Grossberg i Angela McRobbie (red.), Without Guarantees: Essays in Honour of Stuart Hall, London: Verso Press, s. 94-112.

Comaroff, John L. i Jean Comaroff. 2011. Etniczność sp. z o.o., Kraków: WUJ.

Eisenberg, Avigail i Will Kymlicka. 2011. Bringing Institutions Back in How Public Institutions Asses Identity, w: Avigail Eisenberg i Will Kymlicka (red.), Identity Politics in the Public Realm. Bringing Institutions Back in, Vancouver Toronto: UBC Press, s. 1-30.

Eriksen, Thomas Hylland. 1999. Globalization and the politics of identity, „UN Chronicle. The Magazine of the United Nations", autumn, www.eriksen.net [15.05.2014].

Eriksen, Thomas Hylland. 2009. Małe miejsca, wielkie sprawy. Wprowadzenie do antropologii społecznej i kulturowej, Warszawa: Volumen.

Eriksen, Thomas Hylland. 2013, Etniczność i nacjonalizm. Ujęcie antropologiczne. Kraków: Wydawnictwo Uniwersytetu Jagiellońskiego.

Heyes, Cressida. 2002, Identity Politics, “The Stanford Encyclopedia of Philosophy”, http:// plato.stanford.edu/archives/fall2002/entries/identity-politics [15.05.2014].

Gupta, Suman. 2007. Social Constructionist Identity Politics and Literary Studies, Basingstoke: Palgrave Macmillan.

Mazurek, Monika. 2010. Język. Przestrzeń. Pochodzenie. Analiza tożsamości kaszubskiej. Gdańsk: Instytut Kaszubski.

Miller, David. 2000. Citizenship and National Identity, Cambridge: Polity Press.

Nowicka, Ewa. 2004. Etniczność w procesie przemian. „Przegląd Polonijny” 3(113): 9-16.

Synak, Brunon. 2008. Przemiany kaszubskiej tożsamości, w: Andrzej Sakson (red.), Ślazacy, Kaszubi, Mazurzy i Warmiacy - między polskościq a niemieckościa, Poznań: Instytut Zachodni, s. 195-207.

Warmińska, Katarzyna. 2008. Kim jesteśmy? Status etniczny Kaszubów w oczach ideologów grupowych, w: Andrzej Sakson (red.), Ślazacy, Kaszubi, Mazurzy i Warmiacy - między polskościq a niemieckościa, Poznań: Instytut Zachodni, s. 219-231.

Warmińska, Katarzyna. 2013. Polityka a tożsamość. Kaszëbskô Jednota, „Studia Migracyjne. Przegląd Polonijny" 1(9): 189-205.

\section{POLITICS AND IDENTITY}

In the last two decades we have seen important changes in the area of ethnic relations in Poland. Generally speaking, ethnic minorities are becoming more active and better organized actors in the public scene. Their members more openly communicate the needs of the groups, and their goals and visions of the world. To analyse those processes I have decided to apply the concept of identity politics. For that reason I reconstruct the 'logic' of these kinds of activities, focusing on different aspects, perspectives and consequences of this phenomenon. To illustrate my analysis empirically I have taken the example of the Kashubian community.

Key words: ethnicity, politics of identity, Kashubians 